\title{
How to avoid the formation of chlorates and perchlorates during electro-disinfection with diamond anodes?
}

\author{
J. Isidro ${ }^{1}$, D. Brackemeyer ${ }^{2}$, C. Sáez ${ }^{1}$, J. Llanos ${ }^{1, *}$, J. Lobato $^{1}$, P. Cañizares ${ }^{1}$, T. \\ Matthée $^{2}$, M. A. Rodrigo ${ }^{1}$ \\ ${ }^{1}$ Chemical Engineering Department, Faculty of Chemical Sciences and Technologies, \\ University of Castilla-La Mancha, Edificio Enrique Costa Novella. Campus \\ Universitario s/n, 13005 Ciudad Real, Spain \\ ${ }^{2}$ CONDIAS GmbH, Fraunhoferstraße 1b, 25524 Itzehoe- Germany
}

\begin{abstract}
This work focuses on disinfection of water using electrolysis with diamond coatings avoiding or minimizing the formation of hazardous chlorates and perchlorates using a special type of commercial cells designed by CONDIAS (Itzehoe, Germany) in two different sizes: the CabECO and the MIKROZON cells. In these cells, the electrolyte that separates the anode and cathode is a proton exchange membrane. This helps to minimize the production of perchlorate and this behavior is enhanced in the smallest cell for which the very low contact times between the electrodes and the water allows to avoid the production of perchlorates when operating in a single-pass mode, which becomes a really remarkable point. In this paper, we report tests in which we demonstrate this outstanding performance and we also explain the differences observed in the two cells operating with the same water.
\end{abstract}

\section{Keywords}


Electro-disinfection; chlorates; perchlorates; electrochemical cells, CabECO, MIKROZON, ozone

\section{Highlights}

- Cell design is a decisive point for electro-disinfection with diamond electrodes

- Pathogens removed by several log orders with low electric charges

- Chlorates and perchlorates produced in disinfection prevented with cell design

- Great significance of hydraulic residence time on the production of chlorates 


\section{Introduction}

Disinfection using electrochemical methods is becoming a really important technological challenge nowadays [1-4]. Most of the contributions published in the recent years are based on describing the differences in the disinfection efficiencies attained between different types of electrodes (such as MMO or BDD), which may be used in this technology [5]. Other papers, in different ways to avoid the formation of hazardous species, which are particularly relevant when using electrodes consisting of diamond coatings $[6,7]$ and that includes different proposals, such as the combination with other non-electrochemical processes [8-10]. However, not a great attention is payed to the design of the electrochemical cell, which may have a very important impact on the electrocatalytic behavior of the system, promoting or disfavoring the formation of oxidants [11-13]. In this sense, electrochemical cells in which the contact time between the electrodes and the water to be disinfected is low can be a good choice, because they may contribute to prevent the formation of hazardous species like chlorate and perchlorate. This strategy, which can be promoted by using a single pass of the water to be disinfected through the cell, has been evaluated as promising, although it is not the definitive way to address this important problem $[14,15]$.

Oxidation of chlorides to chlorine is a well-known industrial process. Chlorine is formed very efficiently with many different types of electrodes such as platinum or mixed metal oxides (MMO) (Eq. 1). In fact, it is the base of the chlor-alkali industry, which is known to be one of the most important industries in terms of capacity of production. When producing chlorine in aqueous media without separation of the anodic and cathodic compartments of the electrochemical cell, chlorine is disproportionated into chloride and hypochlorite (Eqs. 2 and 3)[9, 16, 17]. 
$2 \mathrm{Cl}^{-} \rightarrow \mathrm{Cl}_{2(\mathrm{aq})}+2 \mathrm{e}^{-}$

$\mathrm{Cl}_{2(\mathrm{aq})}+\mathrm{H}_{2} \mathrm{O} \rightarrow \mathrm{HClO}+\mathrm{H}^{+}+\mathrm{Cl}^{-}$

$\mathrm{HClO} \leftrightarrows \mathrm{H}^{+}+\mathrm{ClO}^{-}$

This process is of a great importance when evaluating the anodic oxidation of wastewater polluted with organics, because hypochlorite leads to a faster removal of organics but producing organo-chlorinated species[18]. This is one of the major handicaps of this environmental application nowadays. However, this challenge has not to be faced when disinfecting water, because of the practically total absence of organics and, here, the electrochemical chlorination has found a very important market, in particular in the disinfection of saline swimming pools and in the disinfection of water for small communities[19].

One decade ago, it was found that chlorine was not the final product of the oxidation of chloride with diamond anodes but, with these electrodes, the reaction continues up to the formation of perchlorates, because of the action of the hydroxyl radicals formed on their surface[20]. It was a very important drawback, because the efficiency in the oxidation attained with these electrodes was much higher and, in fact, they can produce other important oxidants during disinfection (like ozone, peroxocarbonates or peroxophosphates), which can contribute to a more efficient process, making this technology a real breakthrough for disinfection[21-23].

Hence, the differences between the performances of the electrodes are of a major importance. The oxidation of chloride to chlorine can be direct on the surface of the electrode or mediated by hydroxyl radicals. With MMO electrode, the hydroxyl radicals formed during oxidation of water are rapidly combined with the metal oxides of the anode to form transient higher oxidation state oxides. Thus, the reaction of chlorinated species stops there and only ageing of the hypochlorite solution is responsible of the formation of small amounts of chlorate, which had been explained in terms of complex chemical 
mechanisms. However, when using diamond electrodes, hydroxyl radicals do not interact with the surface of the electrode and they are available to combine with hypochlorite, according to the following set of reactions (eqs. 4 and 5), which conduct to the formation of perchlorates.

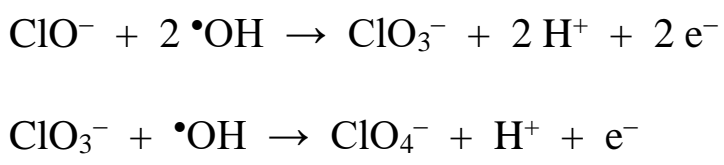

Hence, to avoid the formation of this species, it is very important to prevent the contact between the hydroxyl radicals and the hypochlorite. This paper is focused on the prevention of the formation of chlorates and perchlorates and, to the knowledge of the authors, it is the first paper dealing with this topic in a successful way. Strategy followed is the minimization in the contact time of the electrode with the electrolyte trying to avoid the interactions of hypochlorite with hydroxyl radicals formed on the surface of the diamond anode. It is based on a previous and strange observation. In comparing the performance of two commercial cells manufactured by CONDIAS and equipped with diamond electrodes, we noticed that the production of perchlorate with one of them was, in many tests, negligible or fully inexistent. This behavior was even more unexpected when comparing the cells, because they had exactly the same basic design principles. We decided to face this challenge and to explain the causes shedding light on the way of using diamond electrodes for disinfection without the production of perchlorates. As already explained, this is of a major significance, because the key challenge still needed to be solved for the use of the electrolytic diamond technology in the disinfection of water is how to avoid the production of chlorates and perchlorates during the process.

\section{Materials and Methods}


Electrochemical cells. Electro-disinfection were carried out in two different cells provided by CONDIAS (Itzehoe, Germany). The $\mathrm{CabECO}^{\circledR}$ cells and the MIKROZON ${ }^{\circledR}$ cells are equipped with DIACHEM ${ }^{\circledR}$ electrodes which are built on a substrate that consists of a niobium mesh or a structured silicon substrate respectively (type B) (Figure 1).

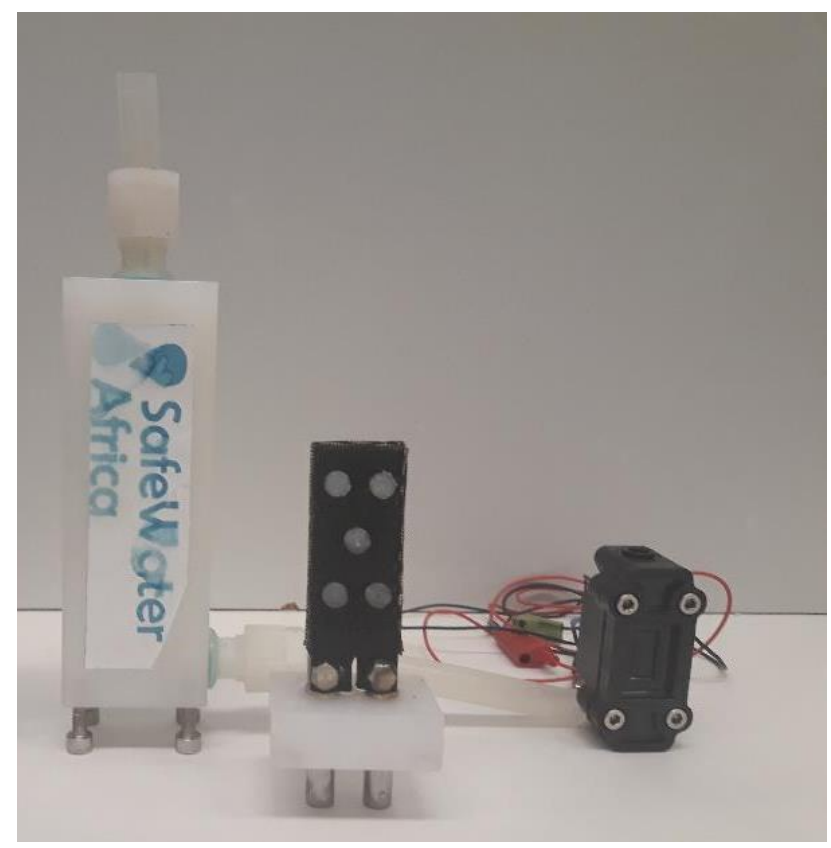

Figure 1. From the left to the right: CabECO (with a detail of its inner part) and MIKROZON cells

The $\mathrm{CabECO}^{\circledR}$ and the MIKROZON ${ }^{\circledR}$ cells are specially designed to produce ozone in low-conductivity water. The $\mathrm{CabECO}^{\circledR}$ has four DIACHEM ${ }^{\circledR}$ electrodes $(50 \times 24 \times 1.3$ $\mathrm{mm}^{3}$ ), which are assembled in two stacks with a NAFION® cation exchange membrane separating the anode and cathode and acting as the electrolyte. The $\mu-\mathrm{CabECO}^{\circledR}$ has two DIACHEM $^{\circledR}$ electrodes $\left(15 \times 7.5 \times 0.725 \mathrm{~mm}^{3}\right)$, which are assembled into a single cell with a fumasep ${ }^{\circledR}$ cation exchange membrane. 
In this work, the electrolyzers were connected to the water reservoir by a peristaltic pump and powered by a Promax DC FA-376 power supply. A Keithley 2000 multimeter was used to monitor the current and cell voltage.

Characterization. Ions concentrations were measured by ion chromatography using a Metrohm 930 Compact IC Flex coupled to a conductivity detector. A Metrosep A Supp 7 column was used to determine anions, by passing through it a mobile phase consisted of $85: 15 \mathrm{v} / \mathrm{v} 3.6 \mathrm{mM} \mathrm{Na} 2 \mathrm{CO}_{3} /$ acetone with a flow rate of $0.8 \mathrm{~cm}^{3} \mathrm{~min}^{-1}$. The temperature of the oven was 45 and $30^{\circ} \mathrm{C}$. The volume injection was $20 \mu \mathrm{L}$. Hypochlorite was analyzed by titration with $0.001 \mathrm{M} \mathrm{As}_{2} \mathrm{O}_{3}$ in $2 \mathrm{M} \mathrm{NaOH}$. Oxidants were determined iodometrically. Microbiological tests conform to standard methods were used: UNE-EN ISO 6222:1999 and UNE-EN 12780:2003 for the quantification of total coliforms and Pseudomonas Aeruginosa, respectively.

\section{Results and Discussion}

Technology of the two cells used in this work is non-conventional for disinfection of water, because the electrolyte is not the treated water but a polymer electrolyte membrane (PEM), which connects directly the anode and the cathode of the cell. Thus, with this technology the conductivity of water to be disinfected is no longer a challenge and the electrochemical disinfection process can be used efficiently, even with water containing very low conductivity. In fact, these cells have been proposed as efficient ozone generators in almost pure water. Regarding the two cells used, the CabECO and the MIKROZON, differences are more in size than in configuration and residence times and contact time of the water with the electrodes are rather different. Figure 2 shows the removal of total coliforms attained with both cells and Figure 3 focuses on the removal of P. Aeruginosa. 

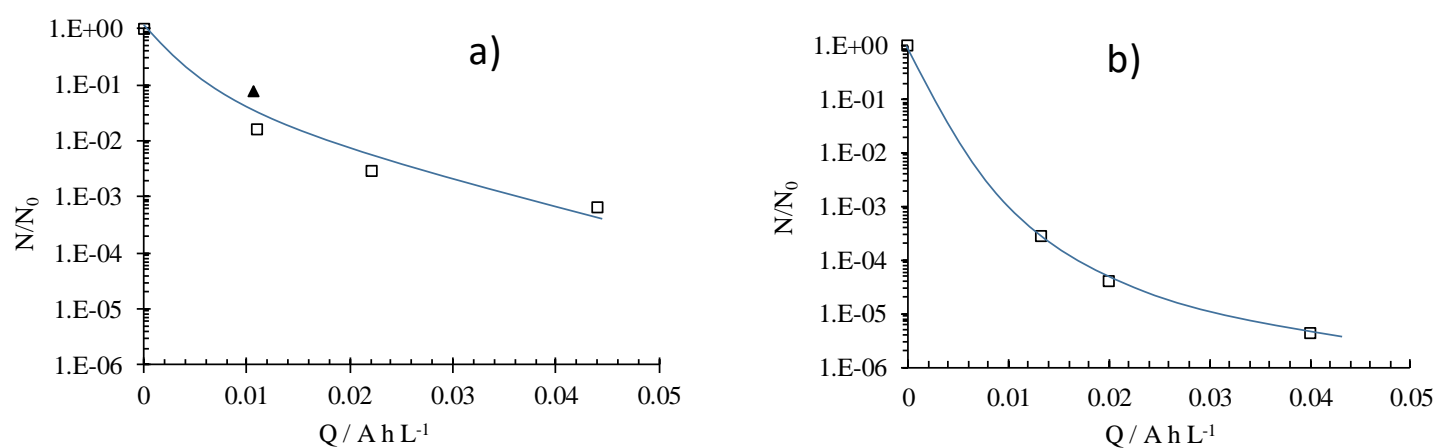

Figure 2. Removal of total coliforms attained by a) CabECO ( $\square 90 \mathrm{~L} \mathrm{~h}^{-1}$ at $1.0,2.0$ and 4.0 A, $\Delta 300 \mathrm{~L} \mathrm{~h}^{-1}$ at 3.2 A) and b) MIKROZON (⒈2 A and 30, 60 and $90 \mathrm{~L} \mathrm{~h}^{-1}$ ) working in continuous mode at different flow rates and current densities as specified.
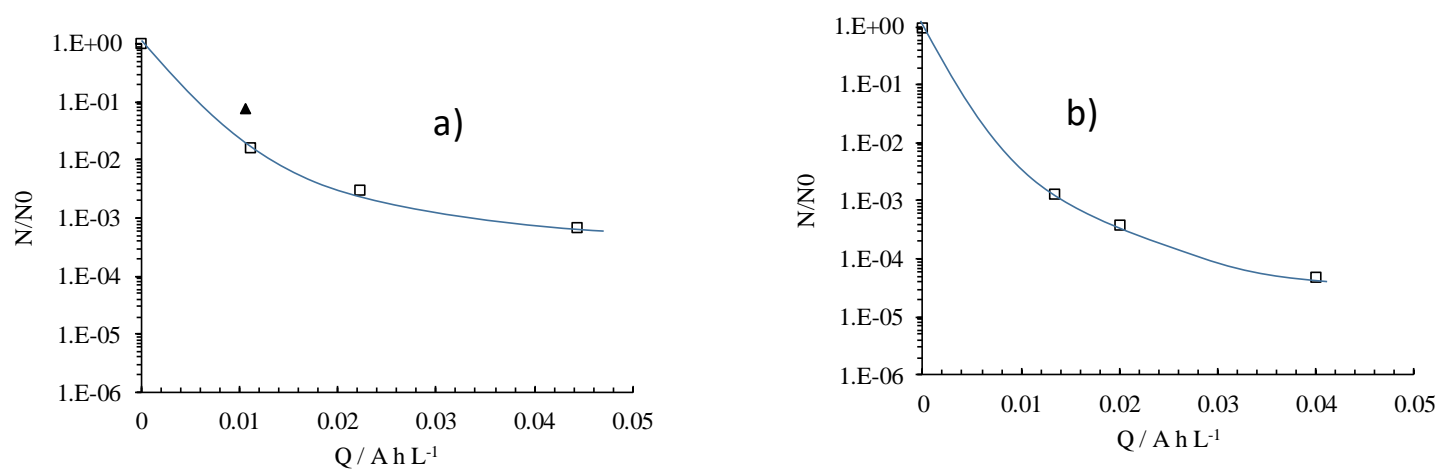

Figure 3. Removal of Pseudomonas Aeruginosa attained by a) CabECO (( $\square 90 \mathrm{~L} \mathrm{~h}^{-1}$ at 1.0, 2.0 and 4.0 A, $\Delta 300 \mathrm{~L} \mathrm{~h}^{-1}$ at 3.2 $\mathrm{A}$ ) and b) MIKROZON (1.2 A and 30, 60 and 90 $\mathrm{L} \mathrm{h}^{-1}$ ) working in continuous mode at different flow rates and current densities as specified.

A clear exponential decrease in the concentration of surviving pathogens is observed, regardless of the flowrate treated and intensity applied, confirming that the specific current passed is the primary operating parameter of the electro-disinfection process. Charge values applied are not very high and this means that disinfection is very efficient because even with power consumptions below $0.734 \mathrm{kWh} \mathrm{m}^{-3}$, it can be attained up to a five-log decrease in the concentration. In comparing the CabECO and the MIKROZON, 
this second cell demonstrates a rather better behavior, being able to remove more than 5$\log$ of Total coliforms and more than 4-log of removal of P. Aeruginosa for charges of only $0.04 \mathrm{Ah} \mathrm{L}^{-1}$. Taking into account the lower cell voltages in this case the power consumption is as low as $0.522 \mathrm{kWh} \mathrm{m}^{-3}$.

Results about disinfection are not surprising, in particular considering the recent works shown in literature about electro-disinfection with diamond coatings (Isidro et al., 2018a; Isidro et al., 2018b). However, they bring up the significance of the cell design on the achievement of high efficiencies in the disinfection technology, especially because of the outstanding results obtained by the special cell concept, in which the electrolyte is not the treated water but a proton exchange membrane that connects the anode and cathode. However, there is also a very important point regarding disinfection with diamond anodes, which should not be avoided in the discussion: the production of chlorates and perchlorates during the electrolysis. It is far away from controversy that efficiency in the generation of oxidants during the electrolysis with diamond anodes is over the values that can be attained with other electrodes such as the MMO electrodes. However, the occurrence of hazardous species has been understood as a major drawback, which need to be addressed.

This can be clearly observed in Figure 4, which shows the speciation of chlorine during the electrolysis carried out with the two cells. Initially, the design concept used in the CabECO and MIKROZON cells is expected to have a good influence on the prevention of the production of chlorates and perchlorates, because the most important electrolyte in the cell are not the salts contained but the proton exchange membrane that separates the anode and the cathode. 

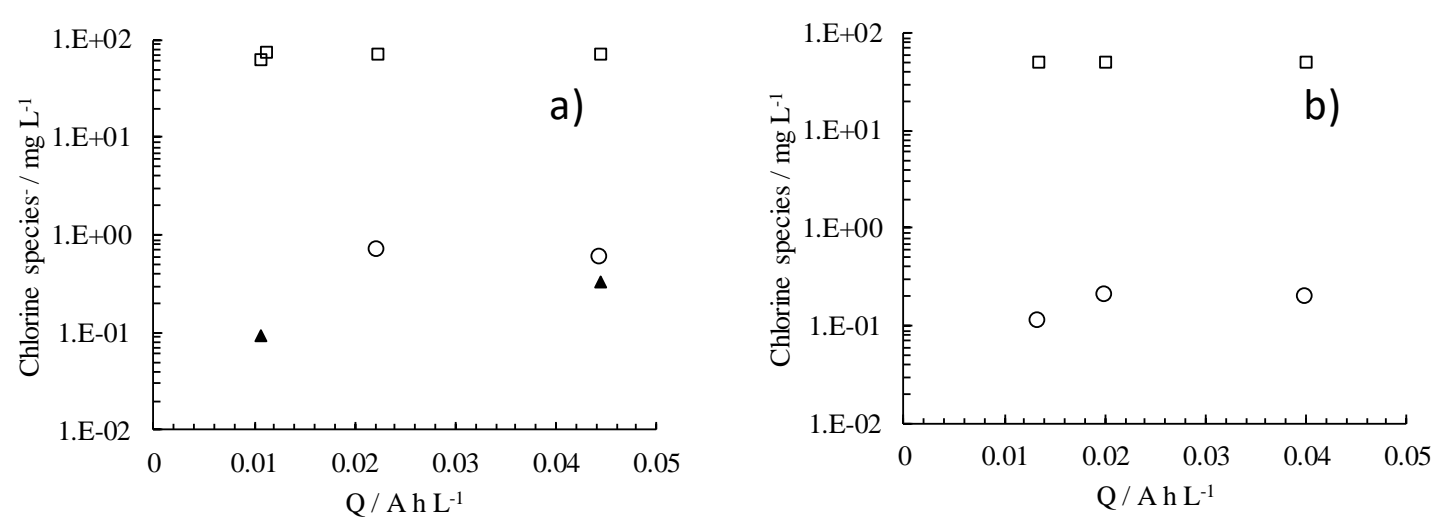

Figure 4. Speciation of chlorine (expressed as $\mathrm{mg} \mathrm{Cl} \mathrm{L}^{-1}$ ) during the electro-disinfection tests carried out with a) CabECO (90 L h$~^{-1}$ at 1.0, 2.0 and 4.0 A and $300 \mathrm{~L} \mathrm{~h}^{-1}$ at $3.2 \mathrm{~A}$ ) and b) MIKROZON (1.2 A and 30, 60 and $90 \mathrm{~L} \mathrm{~h}^{-1}$ ). $\square$ chloride; Ohypochlorite; chlorate; perchlorate.

As expected, the concentration of chlorates is very low in the CabECOcell (more than one log difference in respect to other cells typically proposed for disinfection) and even undetectable in the case of the MIKROZON (below $10 \mu \mathrm{g} \mathrm{L}^{-1}$ ). In addition, in any case perchlorates were detected. This means that the novel configuration proposed for these cells minimize the risk of production of hazardous byproducts and it is particularly relevant in the case of the smallest MIKROZON cell. In fact, this is an outstanding result, because it is the first time that it is reported that complete absence of these two hazardous species can be achieved. However, there is still one important point to be studied: why despite having the same internal configuration, the MIKROZON cell is capable to prevent the formation of chlorates and perchlorates?

Continuous mode and single pass through the cell were pointed out as ways to minimize the impact of the production of chlorate and perchlorate and results obtained in this work confirms this assumption. At this point, the most relevant difference between the CabECO and the MIKROZON is the hydraulic residence time (HRT) of the cells and most particularly, the contact time of the fluid with the electrode, which is close to $0.7 \mathrm{~s}$ in the 
case of the CabECO, (for the flowrate of $90 \mathrm{~L} \mathrm{~h}^{-1}$ ) and only of $0.008-0.024 \mathrm{~s}$ for the MIKROZON (for flowrates in the range $30-90 \mathrm{~L} \mathrm{~h}^{-1}$ ). Formation of perchlorate is a sequential process in which the formation of chlorine (and hypochlorite) is one intermediate step. It is important to maximize its yield trying to avoid that further oxidation. If contact time between the solution containing hypochlorite and the electrode is very short, this further oxidation can be expected to be avoided. This is caused because further oxidation of hypochlorite to chlorates and perchlorates can only occur by the direct action of hydroxyl radicals and the concentration of these radicals is much higher in the proximities of the electrodes.

In order to clarify this point, an additional series of tests was planned using water intensified with E. Coli $\left(2 \cdot 10^{6}-2 \cdot 10^{8} \mathrm{CFU}\right)$ and Pseudomonas Aeruginosa $\left(2 \cdot 10^{6}-\right.$ $\left.3.5 \cdot 10^{9} \mathrm{CFU}\right)$. The series consists of using a sequence of 4 MIKROZON fed with three different flowrates inside the recommended range according to the manufacturer (30-90 $\mathrm{L} \mathrm{h}^{-1}$ to promote good turbulence conditions inside the cell) and operating in continuous operation mode. The outlet of one MIKROZON becomes the inlet of the following. HRT in each cell varied from 0.008 up to $0.024 \mathrm{~s}$ and in the sequence of 4 cells from 0.032 to $0.096 \mathrm{~s}$, still one-fold below of the attained with the CabECO cell. With this experiment, the current charge applied to water and the residence time increase from one cell to the following. Results obtained are shown in Figure 5 regarding disinfection attained (total coliforms; pseudomonas aeruginosa) and 6 regarding hazardous species produced (chlorates) for three different flowrates. Each point corresponds to the steady-state outlet of one single cell. 

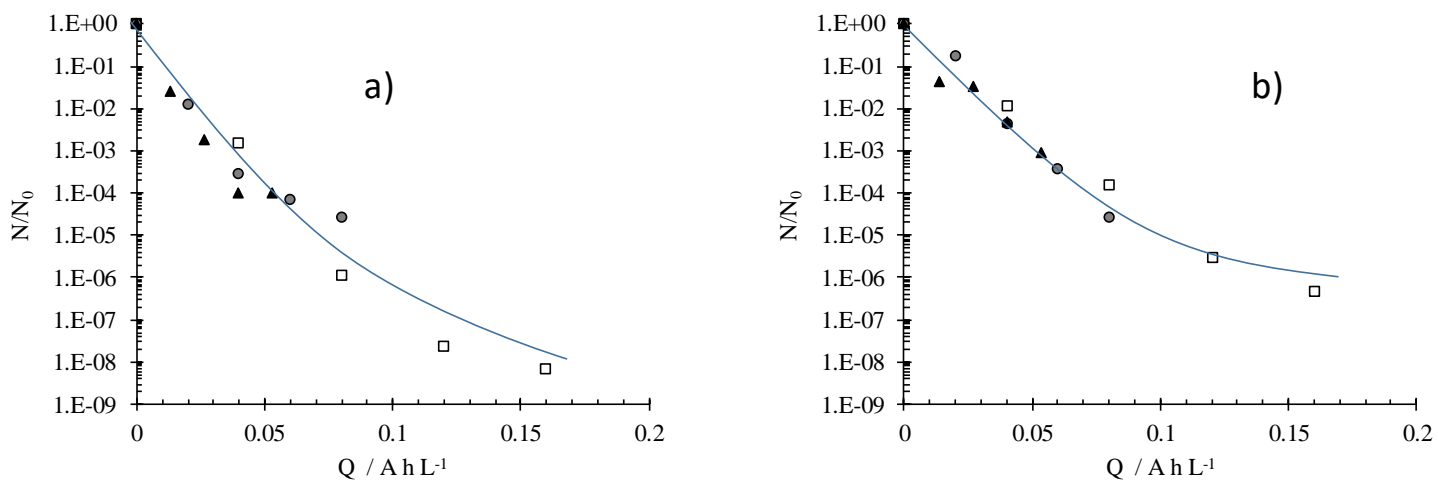

Figure 5. Changes in the total coliform (part a) and Pseudomonas aeruginosa (part b) concentration in a sequence of 4 MIKROZON operated at $30(\square), 60(\bullet)$ and $90(\Delta) \mathrm{L}$ $\mathrm{h}^{-1}$ and the same current intensity $1.2 \mathrm{~A}$.

As expected, the higher the charge applied the higher the removal of pathogens attained. These small cells are capable to reduce more than 6-8 log units in water samples with a very high pathogen concentration. In addition, the low dispersion of the $\mathrm{N} / \mathrm{N}_{0}$ plots informs about the robustness of the technology, which is very important, in particular if taking into account that results are the consequence of the pass of water throughout a different number of cells. 


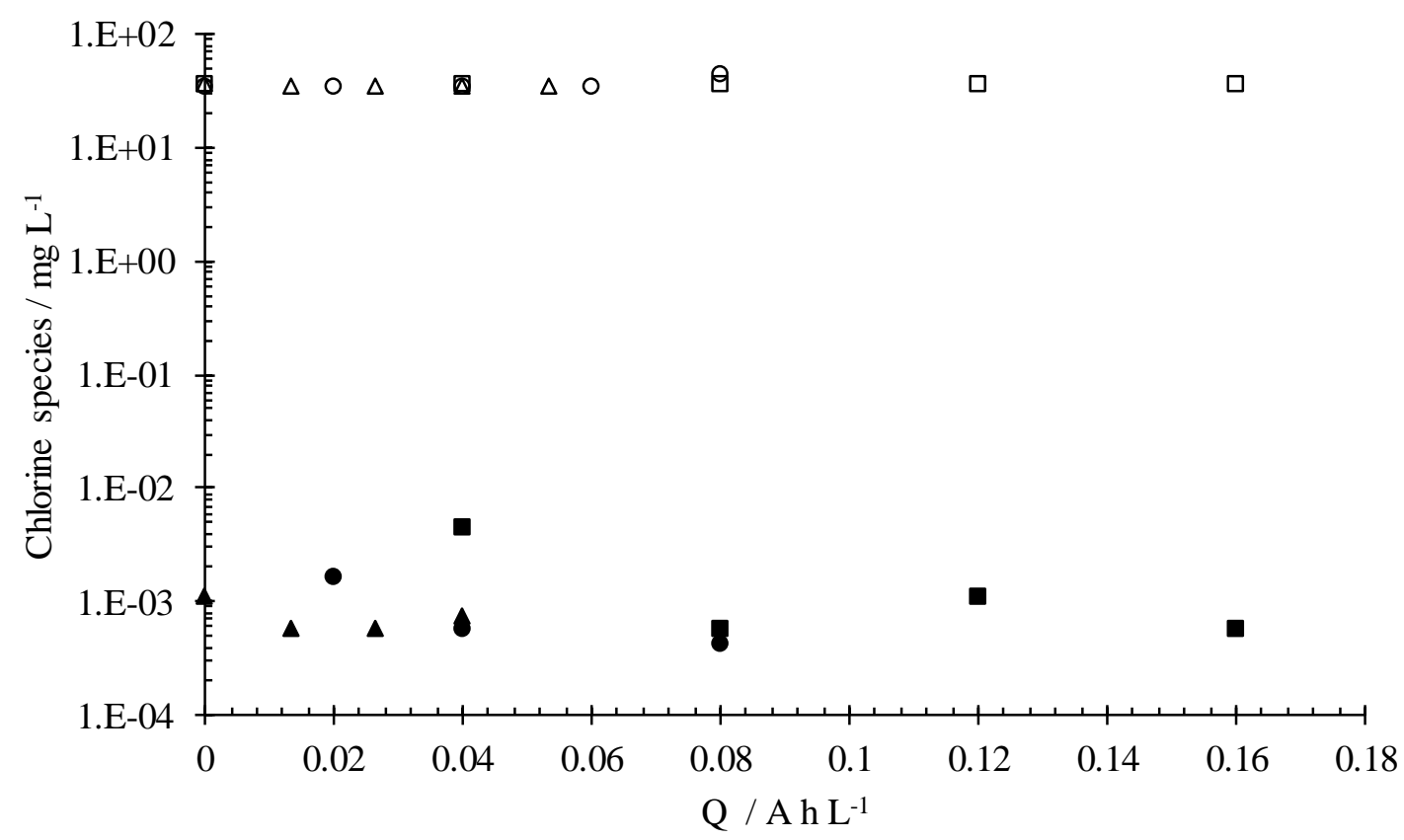

Figure 6. Changes in the chlorine speciation in a sequence of 4 MIKROZON operated at $30(\square, \square), 60(\bullet, \circ)$ and $90(\bullet, \triangle) \mathrm{L} \mathrm{h}^{-1}$ and the same current intensity 1.2 A. Empty symbols: chloride, full symbols: chlorate.

However, what it is more important is the very low concentration of chlorates which, in addition, where initially present in the water used at a level of $1 \mu \mathrm{g} \mathrm{L^{-1 }}$, close to the detection limit of the chromatographic technique used and that, with the use of the cells it does not overcomes the limit of $5 \mu \mathrm{g} \mathrm{L}^{-1}$ in any case. In addition, the very low concentrations of chlorate detected decreased from the tests made with $30 \mathrm{~L} \mathrm{~h}^{-1}$ down to the tests fed with $90 \mathrm{~L} \mathrm{~h}^{-1}$, although in all cases concentration is too negligible to draw any relevant conclusion except for the outstanding performance of the cells, which avoid chlorate and perchlorate formation, even when the residence time is increased up to four times from the recommended values by connecting them in series. Anyway, this trend supports the hypothesis of the great influence the HRT has on the prevention of the formation of chlorates and perchlorates during disinfection. 


\section{Conclusions}

From this work, the following conclusions can be drawn:

- Cells consisting of membrane electrode assemblies such as the commercial cells CabECO and MIKROZON can be efficiently used for the disinfection of water, despite using a polymer exchange membrane as electrolyte instead of water. Although these cells were designed to produce ozone in low conductivity water, they can remove 3-5 logs of CFU with electric charges applied as low as 0.04 Ah $\mathrm{L}^{-1}$. The higher the charge applied, the higher is the disinfection level attained.

- Formation of chlorate and perchlorates during electro-disinfection can be prevented with the use of cells with very low contact time between the water and the electrode and a single-pass strategy. This due to because further oxidation of hypochlorite to chlorates and perchlorates can only occur by the direct reaction of hydroxyl radicals which exist predominantly in the close proximity to the anodes.

- By connecting cells in series, the disinfection attained can be increased and more than 8 -logs have been achieved in the research study made in this work. In any case the $\mathrm{N} / \mathrm{N}_{0}$ follow the same decay trend with respect to the current charge passed regardless of the number of cells attached. Even increasing residence time four-fold, the concentration of chlorates is very low and close to the detection limit of the analytical technique used.

\section{Acknowledgments}

This research belongs to the SafeWaterAfrica project, funded by the European Union's Horizon 2020 research and innovation programme under grant agreement No 689925.

\section{References}


[1] C.A. Martinez-Huitle, E. Brillas, Angewandte Chemie-International Edition 47 (2008) 1998-2005.

[2] N. Ngwenya, E.J. Ncube, J. Parsons, Reviews of Environmental Contamination and Toxicology, Vol 222222 (2013) 111-170.

[3] I. Sires, E. Brillas, M.A. Oturan, M.A. Rodrigo, M. Panizza, Environmental Science and Pollution Research 21 (2014) 8336-8367.

[4] C.A. Martínez-Huitle, M.A. Rodrigo, I. Sirés, O. Scialdone, Chemical Reviews 115 (2015) $13362-13407$.

[5] J. Jeong, C. Kim, J. Yoon, Water Research 43 (2009) 895-901.

[6] H. Bergmann, T. lourtchouk, K. Schops, K. Bouzek, Chem. Eng. J. 85 (2002) 111-117.

[7] H. Bergmann, A.S. Koparal, Electrochim. Acta 50 (2005) 5218-5228.

[8] S. Cotillas, M.J. Martin de Vidales, J. Llanos, C. Saez, P. Canizares, M.A. Rodrigo, J.

Hazard. Mater. 319 (2016) 93-101.

[9] S. Cotillas, J. Llanos, K. Castro-Rios, G. Taborda-Ocampo, M.A. Rodrigo, P. Canizares, Chemosphere 163 (2016) 562-568.

[10] S. Cotillas, E. Lacasa, C. Saez, P. Canizares, M.A. Rodrigo, Applied Catalysis BEnvironmental 229 (2018) 63-70.

[11] M. Fryda, B. Behrendt-Fryda, A. Hampel, L. Heesch, T. Matthee, M. Fischer, W. Schmidt, Acs. Sym.Ser (2016) 128-135.

[12] E.R. Henquin, A.N. Colli, M.E.H. Bergmann, J.M. Bisang, Chem. Eng. Process. 65 (2013) 45-52.

[13] H. Zanin, R.F. Teofilo, A.C. Peterlevitz, U. Oliveira, J.C. de Paiva, H.J. Ceragioli, E.L. Reis, V. Baranauskas, Journal of Applied Electrochemistry 43 (2013) 323-330.

[14] A. Cano, C. Barrera, S. Cotillas, J. Llanos, P. Canizares, M.A. Rodrigo, Chem. Eng. J. 306 (2016) 433-440.

[15] S. Cotillas, M.J.M. de Vidales, J. Llanos, C. Saez, P. Canizares, M.A. Rodrigo, Journal of hazardous materials 319 (2016) 93-101.

[16] C.E. Schaefer, C. Andaya, A. Urtiaga, Chem. Eng. J. 264 (2015) 411-416.

[17] C. Bruguera-Casamada, I. Sires, E. Brillas, R.M. Araujo, Separation and Purification Technology 178 (2017) 224-231.

[18] Y. Li, J.M. Kemper, G. Datuin, A. Akey, W.A. Mitch, R.G. Luthy, Water Research 98 (2016) 354-362.

[19] M.I. Kerwick, S.M. Reddy, A.H.L. Chamberlain, D.M. Holt, Electrochimica Acta 50 (2005) 5270-5277.

[20] A. Sanchez-Carretero, C. Saez, P. Canizares, M.A. Rodrigo, Chemical Engineering Journal 166 (2011) 710-714.

[21] F.R. Julio, T.-P. Hilario, V.M. Mabel, L.C. Raymundo, L.-R. Arturo, R.-V.M. Neftal, Journal of Water and Health 13 (2015) 118-124.

[22] M. Rajab, C. Heim, T. Letzel, J.E. Drewes, B. Helmreich, Chemosphere 121 (2015) 47-53.

[23] P. Valero, M. Verbel, J. Silva-Agredo, R. Mosteo, M.P. Ormad, R.A. Torres-Palma, J.

Environ. Manage. 198 (2017) 256-265. 